http://spilplus.journals.ac.za/

\title{
DIE ROL VAN DIE AKADEMIE IN DIE STANDAARDISERING VAN DIE AFRIKAANSE SPELLING
}

\author{
LC. Eksteen
}

Dit is reeds gebruiklik om na die Suid-Afrikaanse Akademie vir Wetenskap en Runs in die omgang te verwys as "die Akademie". Die laasgenoemde verkorte benaming word dan ook deurgaans in hierdie teks gebruik.

Die Akademie is ' $n$ genootskap met as doelstellings die handhawing en bevordering van die Afrikanse taal, letterkunde en kultuur (en van die Nederlandse taal en letterkunde), asook die bevordering van die SuidAfrikaanse geskiedenis, die kuns, die wetenskap en die toegepaste natuurwetenskapge of tegnologie. Dié liggaam is op 2 Julie 2309 gestig as De zuid-Afrikaanse Akademie voor Taal, Letteren en kunst. In 1921 is dit by private wet (nr. 23) met regspersoonlikheid beklee. In 1959 kom die wet op die Suid-Afrikaanse Akademie vir Wetenskap en Kuns (nr. 54) tot stand; ingevolge hiervan word die statute ook uitgevardig. Onder meer word die Akademie se werksamhede deur sekere vaste kommissies uitgevoer.

Een van hierdie kommissies is die Taalkommissie, wat as een van sy pligte het die opstel van die Afrikaanse spelreëls. Die Afrikaanse woordelys en spelreëls (= Aws) word deur die kommissie opgestel, deur die Akademie goedgekeur en deur die liggaam uitgegee.

Dit is belangrik om in gedagte te hou dat die Akademie (in die persoon van die Akademieraad) die hoogste gesag vorm by die ceëling van die Afrikaanse spelling, en dat die opstel, wysiging en uitbreiding van die spelreëls en verwante sake deur die Taalkommissie gedoen word. Verder word daar by wet bepal dat die Akadenie die bevoegdheid hiertoe bestt. (Vergelyk onder meer Ensiklopedie van die vêreld 9:393; SESA $1: 271-286$, spesifiek pp. 275-276: 
http://spilplus.journals.ac.za/

(Le Roux 1959:44-47); (Malan 1963), vic verdere agtergrond by die bostaande uiteensetting.)

Een van die dringendste take warvoor die Akademie in die jare onmidellik na sy stigting te staan gekom het, was die vasstelling van reëls waarvolgens geskrewe Afrikaans gespel moes word. Die geleidelike erkenning van Afrikaans as onderrigtaal op skool was een van die andeidende oorsake hiertoe.

Voorlopige ortografiese reëls vir Afrikaans is deur T.H. le Roux opgestel. Dit is na ' $n$ Spellingkommissie verwys wat deur Le Roux saamgeroep is. Die lede was J.F.E. Celliers, C.J. Langenhoven, D.F. Malherbe, W.M.R. Malherbe, G.S. Preller en J.D. du Toit, Hierdie reëls is op 18 September 1915 deur die Akademie aangeneem en is in die Jaarboek vir 1915 gepubliseer (vergelyk De Jaarboek, Zuid Afrikaanse Akademie voor Taal, Letteren en Kunst 1915:8097). Dit is ook in ' $n$ afsonderlike uitgawe beskikbaar gestel. Die Akademie het ook besluit "dat ' $n$ woordelijs, bevattende die aangenome spelreëls en op grond darvan, so spoedig molik sal opgestel en uitgegee word" (vergelyk De Jaarboek Zuid Afrikaanse Akademie voor Taal, Letteren en kunst 1915:15). Hiervoor is " $n$ kommissie benoem bestaande uit T.H. le Roux ("konvener"), J.J. Smith en D.F. Malherbe.

In 1917 verskyn dan die eerste uitgawe van die Afrikaanse woordelijs en spelreëls (Le Roux et al 1917), onveranderd "met wegneming van die drukfoute" herdruk in 1918 (Le goux et al 1918:vii). Die kommissie word hierin die "woordelijs-kommissie" genoem. Opvallend hierby is nog die spelvorm "woordelijs". Die gang van die uitgawes van hierdie reëlingslys word kortliks geskets:

(1) In 1921 verskyn die "derde, hersiende druk", warvan die titel verander het na Afrikaanse woordelys en spelreëls (Bosman et al 1921). (Dié titel word hierna onveranderd behou.) Die kommissie word nou die "Woordelyskomitee" genoem. Die betrokke kommissie is in 1918 hersaamgestel, met die byvoeging van J.D. du Toit (wat die benoeming nie aanvaar het nie), en D.B. Bosman. Die opdrag was om die spelreëls deeglik te hersien, veral met betrekking tot sekere probleme wat deur die vertalers van die Bybel in Afri- 
http://spilplus.journals.ac.za/

kaans ondervind is. Die Akademie het hierdie veranderde reëls in 1919 goedgekeur.

(2) In 1931 verskyn die vierde, hersiene en vermeerderde druk (Boshoff et al 1931). Die kommissie heet nou die "Spellingkommissie". Die liggaam is ook uitgebrei met die byvoeging van S.P.E. Boshoff. In die voorwoord word daar sydelings verwys na die groot spellingstryd wat teen die einde van die jare twintig ontbrand het na aanlelding van die "skryfwyse van vreemde woorde", as gevolg warvan daar sekere kompromisse aangegaan moes word, byvoorbeeld oor die reëling van onder meer die spelling van vorme op $i / f e$ en "die opname van meer dubbelspellinge as wat om praktiese tedes gewens is" (Boshoff et al 1931:vii).

(3) In 1937 mak die vyfde, hersiene en vermeerderde druk (= uitgawe) sy verskyning (Boshoff et al 1937). Die kommissie heet nou die "Taalkommissie", die benaming wat voortaan gebruik sou word. Die bykomende lid is L.k. Hiemstra.

(4) In 1953 verskyn die sesde, hersiene uitgawe, wat 'n hele antal herdrukke beleef (Boshoff et al 1953). Bygevoegde lede van die Taalkommissie is S.J. du Toit, W. Rempen en J. du P. Scholtz.

(5) In 1964 verskyn die sewende, verbeterde uitgawe, die tans geldende uitgawe, warvan ook ' $n$ groot aantal herdrukke reeds verskyn het (Boshoff et al 1964). Die komissie is intussen aansienlik uitgebrei, met die byvoeging van M. de Villiers, G.J. Labuscagne, J.s.B. Marais, G.s. Nienaber, F.F. Odendal, F.J. Snijman, S. Strydom, H.J. Terblanche en H.J.J.M. van der Merwe.

(6) Tans word daar gewerk aan die agste uitgawe, wat binne afsienbare tyd die lig behoort te sien. Sedert die publikasie van die sewende uitgawe het die samestelling van die Taalkommissie van tyd tot tyd verander, maar dit is duidelik dat die uitgebreide ledetal van die 1964-kommissie mettertyd aansienlik verlaag is.

Die voorgaande historiese oorsig stel 'n mens in staat om 'n paar relevante sake na vore te bring:

(1) Die geleidelike losmaking van die Nederlands georiënteerde spelwyses. Opvallend in die Spelreëls van 1915 tot 1918 is die optrede van byvoorbeeld 
die ij-spelling (由ij, lijs, fijn,); y in elename en "egte vreemde woorde" (Egypte, hypothese, analygeer); au in soortgelyke vreemde woorde (automaties, auteur, automat); die behoud van $w$ in sekere vorme soos vrouw, leeuw, in die besitlike voornaamwoorde jouw en uw, nuwt, nuws; die behoud van intervokaliese $g$ of $w$ in somige vorme, soos mogelijk of owerlewering, owerigens; die behoud van th (theologie, thesis, thuis): die spelling ou in sekere vreemde woorde (byvoorbeeld troubadour). Sedert die derde vitgawe van die spelreëls in 1921 word baie van die Nederlandsagtige vorme vervang: ij word $y$; $y$ word ie/i; die verval en daar word gespel nus, nut; en vreemde worde word feitlik deur die bank verafrikans: ae word e (pedagoog): ai word ê (affêre); au word ou (outeur); eau word o (buro); é word ee (dinee); $c$ word $k / s$ (kafee; sentrum); $g$ word $s$ (lostes); gn word $n j$ (kampanje); ph word $\mathrm{f}$ (alfabet); qu word kw (kwartaal); rh word r (ritae); $t$ word $s$ (nasie); th word $t$ (teorie); word w (ewolusie); $x$ word $k$ (aksioma); y word ie/i. (tiepe, sipres, Bgipte).

(2) Die groot mate van kontinuiteit in die persone wat oor 'n lang tydperk in die Taalkommissie dien, is opvallend. Vergelyk die volgende tabel:

\begin{tabular}{|c|c|c|c|c|c|c|c|}
\hline & 1915 & $1918^{\circ}$ & 1921 & 1931 & 1937 & 1953 & 196 \\
\hline T.H. le Roux & $x$ & $x$ & $x$ & $x$ & $x$ & $x$ & $\mathrm{x}$ \\
\hline D.F. Malherbe & $x$ & $x$ & $x$ & $x$ & $x$ & $x$ & $x$ \\
\hline J.J. Smith & & $x$ & $x$ & & & & \\
\hline D.B. Bosman & & & $x$ & $x$ & $x$ & & \\
\hline S.P.E. Boshofe & & & & $x$ & $x$ & $x$ & $x$ \\
\hline L.W. Hiemstra & & & & & $x$ & $x$ & $\mathrm{x}$ \\
\hline S.J. du Toit & & & & & & $x$ & $\mathrm{x}$ \\
\hline w. Kempen & & & & & & $x$ & $\mathrm{x}$ \\
\hline J. du P. Scholt & & & & & & $x$ & \\
\hline
\end{tabular}

(Die groot antal nuwe lede wat meewerk aan die 1964-lys word hierbo buite rekening gelaat (M. de Villiers, G.J. Labuscagne, J.S.B. Marais, G.S. Nienaber, F.F. Odendal, F.J. Snijman, S. Strydom, H.J. Terblanche, H.J.J.M. van der Merwe); van hierdie groep bly net F.F. Odendal in die huidige Taalkommissie (1984) oor,)

T.H. le Roux staan yader vir die oorspronklike spelreëls van 1915 en hy en D.F. Malherbe he: Jus die langste diens gehad, daarna volg S.P.E. Boshoff 
en dan D.B. Bosman en L.W. Hiemstra. Dit is warskynlik dat hierdie kontinuiteit baie darmee te doen kan hê dat die Afrikanse woordelys en spelreëls ' $n$ bepaalde vorm en inhoud oor die jare vertoon het. Die geleidelike, maar soms ook vertraagde, verafrikaansing van die spelreëls kan moontlik ook aan die invloed van hierdie medewerkers toegeskryf word. Dit is ' $n$ saak wat verdere, diepgaande ondersoek verdien, maar tans word daar nie verder op die aangeleentheid ingegaan nie.

(3) Die tussenposes warin die Aws versorg en gepubliseer word, word oor die algemeen met die jare groter. Vergelyk die volgende tabel:

$\begin{array}{llllllll}1915 & 1917 & 1918 & 1921 & 1931 & 1937 & 1953 & 1964 \\ \text { Jaar } & 2 & 1 & 3 & 10 & 6 & 16 & 11\end{array}$

Sedert 1964 het daar nou reeds 20 jaar verloop. Sonder dat 'n nuwe ultgawe verskyn het. Hierdie verlenging van die tydperk tussen nut bewerkte uitgawes kan, benewens aan sekere eksterne faktore conder andere wêreldoor log II tussen uitgawes 5 en 61 , onder meer daaraan toegeskryf word dat die basiese spellingreëling reeds ' $n$ bepalde vaste patcoon aangeneem het. Sedert 1964 kom daar egter waarskynlik ' $n$ nuwe dimensie by: ' $n$ groot aantal jonger taalkundiges begin van tyd tot tyd in die Taalkommissie dien, bring nuwe insigte, die formulering van die spelreëls word aan ingrypende kritiek onderwerp en feitlik in totaal herskryf en die Woordelys word insgelyks in belangrike mate òf gewysig òf uitgebrei.

\section{2}

Die Akademie as normerende liggaam

2.1

Die status van die Akademie

Die Akademie het by wet die status om bepaalde doelstellings na te streef en te bevorder (sien par. 1.1 hierbo). Een van die doelsetllings raak die bevordering van AErikaans en een onderdeel hiervan is die reëling van die Afrikaanse spelling. Die werksdamhede in dié verband word sedert 1915 deur die Akademie aan die Taalkommissie toegewys, mar alle besluite van die Taalkommissie moet natuurlik deur die Akademieraad bekragtig word. 
http://spilplus.journals.ac.za/

Met verloop van jare het die werksaanhede van die Taalkommissie aansienlik uitgebrei. Hoewel die voorgangers van dié liggaam, veral in die beginjace van die reëling van die Afrikaanse spelling, hulle hoofsaaklik met spellingnormering besig gehou het, het die posisie gaandeweg verander, sodat die Taalkommissie mettectyd ook uitsprake begin doen het oor breëre taalgebruiksaangeleenthede en veral gereeld advies dan allerlei instansies gee oar problematiese aspekte, veral ook oor sake waaroor daar nie uitsluitsel in die Aws gevind kan word nie. Die Taalkomissie is lank reeds nie meer net in spellingreëlingskommissie nie.

Vir die doeleindes van hierdie artikel word daar egter net gewys op die rol van die Taalkommissie in die reëling of normering van die Afrikanse spelling. Uit die voorafgaande oorsig in par. 1 is dit duidelik dat die Taalkomissie die rol vervul van opsteller van die norme wat by die spelling en skryfwyse van Afrikaanse skriftelike talgebruik geld, Die "skriftelike talgebruik" warvan hier gewag gemaak word, raak slegs.die standaardvorm van Afrikaans. Dit is hierdie gebruiksvorm wat deut die Taalkommissie vasgestel en in die vorm van reëls neergelê moet word. Een sentrale probleem hierby is die vasstelling van wat as standaardafrikaans beskou moet word. Die oogmerke met die reëling van die Afrikaanse spelling kan gevolglik soos volg gestel word:

(1) Die normering van Afrikaanse spelvorme.

(2) Die formulering van beginsels op grond warvan hierdie norme vasgestel kan word.

(3) Die opstel van spelreëls war in hierdie norme uitgedruk word.

(4) Die beskikbaarstelling van die spelreëls.

(5) Die beskikbaarstelling van in woordelys van spelvorme warin daar onder meer konkreet aangedui word hoe bepaalde vorme gespel/geskryf moet word en warin daar ook voorbeelde van moeilike/vreemde vorme opgeneem word. 
(1) Algemene grondbeginsels

(2) Die gebruikte lettertekens

(3) Klinkers en tweeklanke

(4) Medeklinkers

(5) Enkele taalvorme (war in vorme soos $s^{\circ} n$, alj (slj), die toonlose e, deelwoorde en sekere wisselvorme betrek word).

Sekere aanvullinge by die spelreëls van 1915 word as addisionele afdeling in die drukke van 1917 en 1918 bygevoeg. Dit raak onder meer die opname van sogenaamde minder gebruiklike vorme, van verboë vorme van die b.nw.. die gebruik van afkappingstekens, die skryfwyse van saangestelde telwoorde met koppeltekens, die los skryf van stofaanduidende s.nwe., die verdubbeling al dan nie van $s$ in samestellings, die gebruik van * in buigingsvorme, die gebruik van hoof letters, ensovoorts.

Opvallend hier is dat daar dikwels nog nie van rubrisering gebruik gemak word nie, maar dat spelvorme ad hoc ingedeel word.

Hierin word die afdeling oor spelreëls onder die volgende hoties ingedeel:

(1) Algemene spellingbeginsels. Die lettertekens.

(2) Klinkers en tweeklanke

(3) Medeklinkers

(4) Nog enige spellingkwessies en taalvorme

Die indeling van die ligs-1918-reëls in ses onderskeibare, en soms losstaande afdelings word nou weliswar tot vier benoemde onderafdelings 


\begin{abstract}
Eksteen $\quad 176$ gereduseer, mar die laste afdeling word nie verder onderverdeel en gegroepeer nie. Tog word die reëls wat in die vorige uitgawe nog as bykomende afdeling verskyn, nou in die uiteensetting van die spelreëls geïnorporeer en al die betrokke paragrawe word deurlopend genommer. Sekere spelreëls is ook gewysig of aangepas.
\end{abstract}

3.3

Die indeling van 1931

In hierdie vierde uitgawe kom daar 'n aansienlike rasionalisering en uitbreiding van die spelreëls, warin bepaalde aspekte wat die spelling (en skryfwysel raak, nou vir die eerste keer 'n duidelike patroon het. Met hierdie uitgawe kry ons dus ook die eerste gesistematiseerde uiteensetting van die spelreëls. Hier volg die indeling:

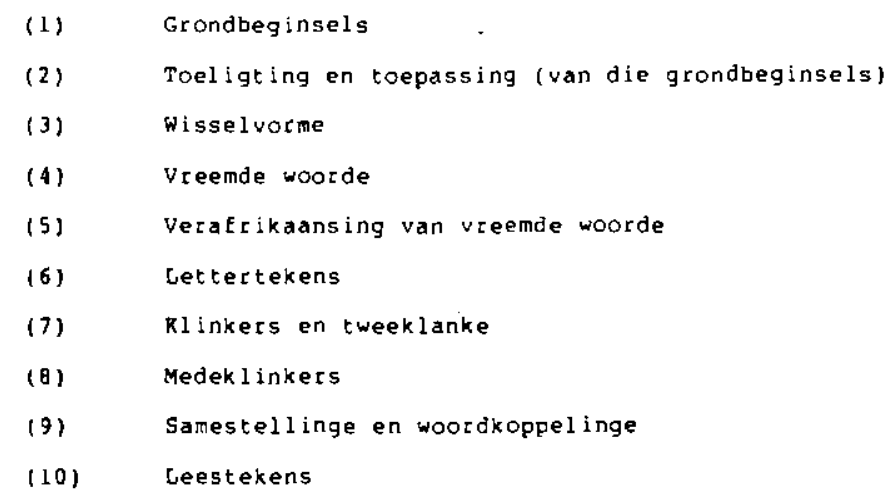

Opvallend hierby is nie net die meer rasionele ordening van sake rakende die beginsels warvolgens die spellingnorme vasgestel word en die spesifieke spellingnorme self nie, mat ook die onderskeiding en aanduiding van afdelings wat spesifiek tot probleme anleiding gee, byvoorbeeld wisselvorme en vreemde woorde (asook die verafrikaansing hiervan), asook in afsonderlike afdeling met leiding (of norme?) by interpunksie, dit wil sê nie streng gesproke 'n spellingaangeleentheid nie, maar wel in aspek van skriftelike taalgebruik waroor daar probleme na vore kan kom, (Die afdeling is deur A.C. Bouman in opdrag van die Akademie versorg, en vorm nie ' $n$ afdeling van die spelreëls as sodanig nie. Vergelyk (Boshoff et al $1931:$ vii)., 
http://spilplus.journals.ac.za/

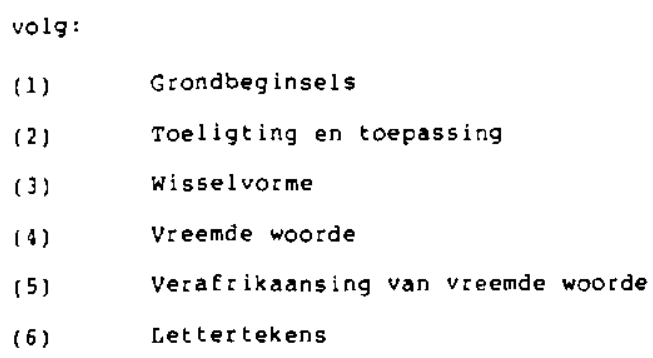

Hierdie uitgawe bring weer eens ' $n$ verandering in die Indeling, hoewel die onderliggende patroon dieselfde bly. Opmerklik is dat rasionalisasie dié keer anders geskied: sekere afdelings wat viceër geskei is, word bymekaar gegroepeer (so is daar nou slegs een afdeling oor die grondbeginsels), nuwe afdelings word bygevoeg, terwyl sekete indelings heeltemal verval het. Hier volg die indeling: 


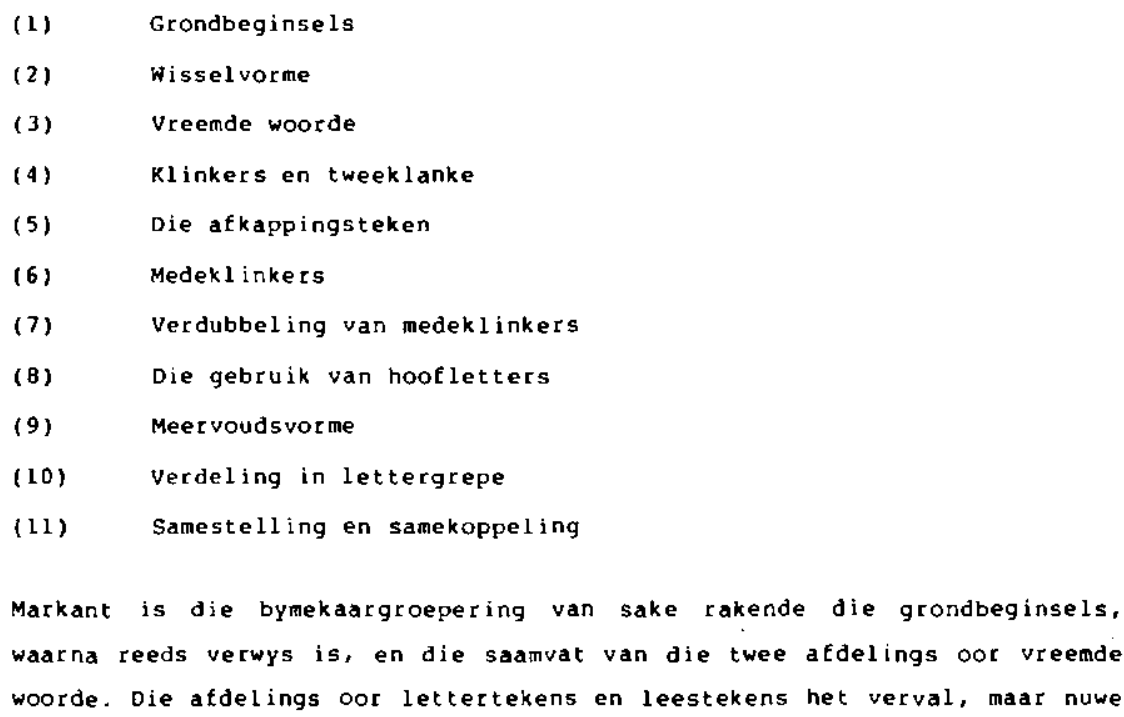

Die Indeling van hierdie uitgawe toon in hoë mate ' $n$ nuwe rubrisering, en die dantal afdelings word tot sestien vermeerder. Die rasionalisering wat telkens in die vorige uitgawes geskied het, word gevolglik verder gevoer. Verbandhoudende spellingsake word ook in volgorde bymekaar, gegroepeer. Hier volg die indeling:

\begin{tabular}{|c|c|}
\hline (1) & Grondbeginsels \\
\hline (2) & Dubbelspellinge \\
\hline (3) & wisselvorme \\
\hline (4) & Doeblette \\
\hline (5) & Skeiding van woorddele by skryf \\
\hline (6) & Deeltekens \\
\hline (7) & Koppel tekens \\
\hline (8) & Afkappings tekens \\
\hline (9) & Kappies \\
\hline (i0) & Aksent tekens \\
\hline (11) & klinkers en tweeklanke \\
\hline (12) & Medeklinkers \\
\hline
\end{tabular}


http://spilplus.journals.ac.za/

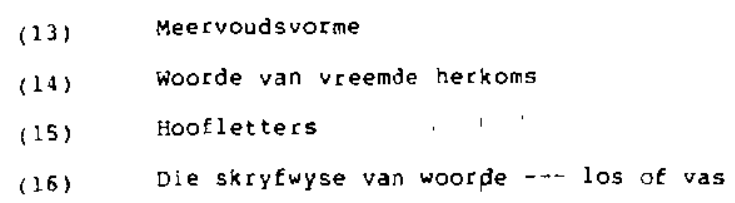

Opvallend hierby is dat daar nou vir die eeste keer ' $n$ (uitvoerige) afdeling bygevoeg is oor die los af vas skryf van woorde, terwyl spesifieke spellingaspekte, byroorbeeld die gebruik van deeltekens, koppeltekens, afkappingstekens en aksenttekens, nou in afsonderlike afdelings gehuisves word. Die afdeling oor wisselvorme word ook uitgebrei, sodat afsonderlike indelings vir dubbelspellinge en doeblette ingeruim word. Afdelings van die 1953-uitgawe wat verval het, is dié oor samestelling en samekoppeling en dié oor die verdubbeling van medeklinkers, wat in die betrokke rubrieke war dit tuishoort, ondervang word.

Van die eerste uitgawe van die Aws in 1917 verskyn daar as tweede afdeling 'n woordelys: hierin word 'n keuselys van woorde gegee wat, oor die algemeen, gebruik kan word vir die naslaan van spesifieke vorme, meesal dié warmee die gebruiker probleme ondervind. Dit is moontlik ' $n$ aandulding van die toenemende skriftelike gebruik van Afrikaans dat hierdie woordelysgedeeltes oor die jare in omvang sou toeneem. Vergelyk die volgende tabel warin die aantal woorde per uitgawe by benadering aangegee word:

$\begin{array}{ll}\text { Uitqawe } & \text { woorde } \\ 1917 / 18 & 15680 \\ 1921 & 16400 \\ 1931 & 28688 \\ 1937 & 29040 \\ 1953 & 20560 \\ 1964 & 26102\end{array}$

Die vermindering in 1953 ten opsigte van 1937 lê daarin dat "'n groot aantal woorde en/of woordvorme uit die vorige woordelys $(\ldots)$ geskrap" is (Boshoff et al 1953: L). Die toename in 1964 ten opslgte van 1953 lê daarin dat, hoewel dar weer woorde/woordvorme geskrap is, veral tegniese en natuurwetenskaplike terme asook streekspraakwoorde, bygevoeg is (Boshof et al 1364, voorwoord p. 11. 
Hierby kom dat dat 'n lys van afkortings (ongeveer 1200 ) by die 1953-uitgawe gevoeg is, asook by die 1964-uitgawe $( \pm$ 1280). Hierdie lyste word telkens vooraf gegaan deur 'n kort koeligting, want afkortings word nie beleël nie.

Dit sou ' $n$ insiggewende studie wees om vas te stel op watter grondslag die betrokke vorme in die woordelys telkens gekies is. By ' $n$ oppervlakkige deurgaan van die material kry mens die indruk dat daar nie op grond van sekere vaste uitgangspunte besluit is om sekere tipes problematiese gevalle op te neem nie, maar dat dié opnames eerder ad hoc van aard is. Ongelukkig kan die aangeleentheid nie hier verder gevoer word nie. Dit blyk egter wenslik te wees om die woordelys aansienlik wit te brei en om sorg te dra dat soveel probleemtipes as moontlik in die woordelys opgeneem word, aangesien die praktyk leer dat die Aws-gebruiker hoofsaaklik die woordelys naslaan, eerder as om die betrokke spelreël na te slaan en toe te pas. TTerloops: die naslaan van die spelreëls is dikwels moeilik, aangesien dit dikwels nie uit te mak is presies waar ' $n$ betrokke probleemgeval daarin behandel word nie. Slegs die 1953-uitgawe het 'n bladwyser bevat, wat besonder nuttig was,

Uit die voorgaande algemene skets van die geleidelike ontwikkeling van die northering van die Afrikaanse ortografie, blyk die volgende verskynsels:

(1) Daar is een gesaghebbende liggaam vir die reëling van die Afrikaanse spelling, namlik die Akademie, wat hom sedert 1915 hiermee besig hou.

(2) Aanvanklik is die hegte inskakeling by Nederlands nog opvallend aanwesig, mar mettertyd is daar ' $n$ al hoe groter beweging in die rigting van veraf rikaansing.

(3) Die spelreëls word aanvanklik min of meer in algemene rubrieke onderverdeel, sonder in te presiese rubrisering. Mettertyd kom daar groter presisering en word dar gerubriseer op grond van die opvaliende kenmerke van die geskrewe Afrikanse woordvorm/skryfvorm.

(9) Die basiese skryf-en spellingsisteem van Afrikaans is reeds teen ongeveer 1964 vasgelê, met aan die een kant ' $n$ aansluiting by sekere tradi- 
http://spilplus.journals.ac.za/

Eksteen 181

sies fonder meer die Nederlandse tradisiel en aan die ander kant 'n vaslegging van Afrikaanse vorme op grond van sekere reëls/norme, wat dikwels berus op sekere standardvorme in die Afrikaanse uitspraak, of wat die beginsel van gelykvormigheid betrek. Oor die algemeen is daar dus redelike vastheid ten opsigte van die aanvarde en vasgestelde grondbeginsels waarop die Afrikaanse spelreëls berus.

(5) Daar is toenemend ' $n$ geneigdheid or al hoe meer min of meer afwykende vorme, byvoorbeeld ten opsigte van vreende woorde, of ten opsigte van die uitsonderings op die geformuleerde spelreëls, in die groter kader van die reëls tuis te bring, al beteken dit dat die reëls uitgebrei en aangepas moet word.Verder in dié artikel word op sekere van die genoemde kwessies nader ingegaan.

\section{Die Afrikaanse spelreëls}

\section{Die beginsels van normering}

Wat die beginsels van normering ten opsigte van die Afrikaanse spelling betref, kan die volgende gestel word:

(1) Die spelling/skryfwyse van woorde en woordvorme (byvoorbeeld meervoudsvorme, graadtrapvorme, werkwoordsvorme) is ' $n$ skriftelike aangeleentheid: spelling het te doen met weergawes op skrif. Skriftelike taalgebruik streef waarskynlik na eenvormigheid: 'n woord/woordvorm moet konsekwent een vorm vertoon. Selfs in tale warin die spelvorme nie bewustelik gereël wora nje, kom daar mettertyd -.- op grond van verskeie oorwegings, onder andere die gesaghebbendheid van instansies (waaronder publikasies), die aanvarding deur' $n$ groot gros skriftelike taalgebruikers, die neerlê van vorme in 'n spelboekie (byvoorbeeld vir skoolgebruik) --- 'n groot mate van eenvormigheid en konsekwentheid tot stand. Waar die spelvorme bewustelik gereël moet word, kom daar nou die element van rasionalisasie of bewuste reëlskepping na vore. Dit lei daartoe dat daar bewustelik norme geskep moet word warvolgens die spelling moet geskied, of waarop die spelling moet berus. So ' $n$ verskynsel geld byvoorbeeld vir die spelling van die afrikatale, by ons spesitiek die Bantoetale.

Die geval van Afrikaans laat ' $n$ ander dimensie na vore kom: enersyds het Afrikaans ontwikkel tot selfstandige standaardaal, maar andersyds het dit 
-.- veral wat sekere skriftelike gebruike betref -.. nou by Nederlands aangesluit. Hoewel ' $n$ groot hoeveelheid van die Nederlandse ballas afgeskud is, is daar nog heelwat spellinggebruike wat die Nederlandse tradisie in Afrikaans bestendig. Die dimensie wat bykom, is gevolglik die tradisionele: sulke tradisionele vorme kan nie altyd verantwoord word aan die Afrikaanse taalsisteem nie. Hierdie aansluiting by of bestendiging van tradisionele vorme in Afrikaans is een van die probleme wat die normopsteller vir die Afrikanse ortografie teenkom. Hierby moet ook in gedagte gehou word dat die Afrikaanse woordeskat, benewens die Nederlandse element, ook heelwat leksikale items bevat wat aan die sogenaamde vreemde of ook aan die klassieke tale ontspring, en wat ò via Nederlands òf direk in Af $\mathrm{i}$ ikaans oorgebring word. Hierby kan daar dus gevalle na vore tree wat of by die (tradisionele) Nederlandse spelling aansluit, of wat in die Afrikaanse spelsisteem verantwoord (kan) word. Dit kan dan aanleiding gee tot inkonsekwentheid in die Af $r$ kaanse spelling.

(2) Die voorgaande sluit aan by ' $n$ volgende kenmerk wat eie aas spellingreëling is: dit is preskriptief van aard. Op ' $n$ sekere vlak van taalgebruik, namlik die skriftelike, word daar aan die taalgebruikers voorgeskryf hoe ' $n$ bepaalde woord/vorm gespel resp. geskryf moet word. Hierdie preskriptiwiteit word egter in belangrike mate deur die volgende oorwegings gekwal if iseer:

(a) Die preskriptiewe norme geld slegs vir die skriftelike weergawe van die sogenaamde standardtaal (of algemeen beskafde taalvorm, soos dit vroeër algemeen genoem is).

(b) Die handhawing van die betrokke voorgeskrewe norme is om verskillende redes nie (altyd) afdwingbaar nie. ' $n$ Aantal hiervan is:

(i) Skriftelike talgebruikers is onbewus van die draagwydte van ' $n$ bepaalde spelreël (of reeks spelreëls). Sulke reëls kan dan nie altyd konsekwent toegepas word nie.

(ii) Bepaalde instansies behou hulle die reg voor om sekere vorme te gebruik, bewustelik of onbewustelik in afwyking van die voorgeskrewe reëls. 
http://spilplus.journals.ac.za/

(iii) Die onderrig van die reêls stuit op probleme van interpretasie by bepaalde reëls.

(iv) Die reëls self lei tot botsende interpretasies: volgens die een reël kan ' $n$ bepalde spelling gevolg word, terwyl 'n ander reël 'n ander spelvorm tot gevolg kan hê.

'n Voorbeeld by (i) is die spelvorm technikon wat deur die Departement van Nasionale opvoeding ingevoer is, sonder inagneming van dle verbandhoudende vorme tegniek, tegnies, tegnologie(s). By (ii) is ' $n$ voorbeeld die skryfwyse blankes, swartes, (dit wil sê sonder die hoofletter) in sekere koerante (byvoorbeeld die van die Nasionale Pers), of die spelvorm benodighede (in plaas van benodigdhede) wat dikwels teengekom word. In die geval van (iii) is daar die gebruik van die kappie in woorde soos skêr en blêr, marar nie byvoorbeeld in woorde soos ver of pers (=kleur) nie. By (iv) kan genoem word die gebruik van die koppelteken al dan nie in gevalle soos anticunaties, anti-rooktablet, anti-Russies (maar byvoorbeeld verafrikaans), antirevolusioner (en hoe word vorme met byvoorbeeld prohanteer?): of kalorineter teenoor kaloriewaarde.

(3) Die grondslae warop normering (moet) berus, word verder gekompliseer deur die vraag: in hoe 'n mate is dit moontlik om die standaardvorm van die betrokke taal vas te stel? kierdie kwessie word later in die artikel geïllustreer met verwysing na die hantering van wisselvorme. Die kwessie gee ook aanleiding tot die onderskeiding van bepalde grondbeginsels warop die Afrikaanse spelling dan berus. Dit word in die volgende paragraat behandel.

Dit is tot dusver in hierdie algemene oorsig duldelik dat daar minstens twee tipes norme geld:

(1) Die norm van die algemene beginsels wat moet geld vir die spellingreëling. Dit is deur die verskillende taalkommissies heen verwoord in die sogenaamde grondbeginsels. Ons noem dan dié tipe norme "beginselnorme". 
(2) Die narme wat in 'n groot aantal subtipes verdeel word, mar wat ten doel het die vaslegging van reëls waraan die skriftelike vorm van woorde moet voldoen. Hierdie tipe notme noem ek vervolgens "spelnorme".

Die onderskeiding van die grondbeginsels warop die Afrikaanse spelling berus, is oor die jare min of meer konstant gehandhaaf, behalwe dat die formulering daruan dikwels gewysig is.

'n Kort oorsig lewer die volgende ten opsigte van die stelwyse van hierdie grondbeginsels: In die eerste uitgawe van die Afrikanse woordelijs en spelreëls (1917), soos in die Afrikaanse spelreëls (1915). verskyn vyf "algemene grondbeginsels":

(a) Vir so ver moontlik, elke klank deur 'n aparte letter voor te stel, en geen onnodige letters te gebruik nie.

(b) Dieselfde woord, voor- of agtervoegsel, vir so ver moontlik, altyd op dieselfde wyse te skrywe.

(c) Die geskiedenis net daar in ag te neem war dit om praktiese redes noodsaaklik is.

(d) So weinig moontlik van die Vereenvoudigde Hollandse spelling af te wyk.

(e) Altyd die mees gebruiklike uitspraak weer te gee, en dit as norm aan te neem.

Punt (d) verander in die 3de hersiene druk (1921) na:

Nie onnodig van die Vereenvoudigde Nederlandse Spelling (V.N.S.) af te wyk nie.

Maar dan, in die 4de hersiene en vermeerderde druk van 1931 , verminder die grondbeginsels na drie:

Die Afrikanse spelling wil:

(1) die algemeen gebruiklike uitspraak in beskafde Afrixaans weergee:

(2) by die Vereenvoudigde Nederlandse spelling (V.N.S.) aansluit en nie sterk daarvan afwyk nie;

(3) so ver moontlik gelykvormig wees. 
http://spilplus.journals.ac.za/

In die 5de hersiene en vermeerderde uitgawe (1937) is daar weer eens slegs 'n verandering wat punt (2) betref: "nie sterk daarvan afwyk nie" word "nie onnodig daarvan afwyk nie".

In die 6de hersiene uitgawe (1953) is daar weer 'n verandering wat punt (2) betref. Nou lui dit:

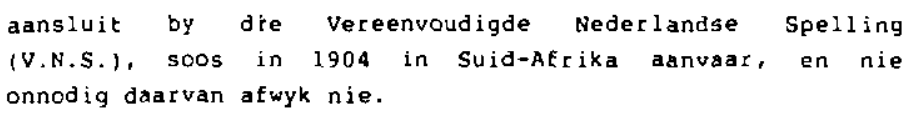

ook punt (1) word nou anders geformuleer:

(1) die algemeen gebruiklike uitspraak in beskafde Afrikaans as grondslag aanvaar.

En dan in die 7 de verbeterde uitgawe (1964) word punt (2) nog in keer gewysig:

rexening hou met die spelling wat vandag amptelik in Nederland erken word.

Dit is uit hierdie opsomming duidelik dat die opeenvolgende taalkommissies groot probleme ondervind het met die sogenaamde aansluiting by die Nederlandse spelling. Waarom sou dit wees? Die ander grondbeginsels word duideliker en presieser geformuleer -.- en daarmee $x a n$ ' $n$ konsekwente of ' gestandaardiseerde spelling vir Afrikaans gereël word, soos inderdaad dan ook oor die jare gebeur het. Maar die Nederlandse aspek moet telkens weer eens opnut na vore gestoot word om die par gevalle te verantwoord waarby daar nie uitgegaan is van die vorme wat konsekwent eenders gespel behoort te word nie, sou ' $n$ mens uitgaan van ' $n$ konsekwente, Afrikaanse reëling: dit geld dan spesifiek die voorkoms van $v \times f$ en $y \times e i$.

In hierdie verband is Le Roux (1959:45) se opmerking ter sake:

"Nog ' $n$ verskil in die verskillende drukke is dat gaandeweg probeer is om die spelling van Afrikaans meer uit Afrikaans self op te stel, sonder ewenwel onnodig af te wyk van die Vereenvoudigde Nederlandse Spelling. Die band met Nederlands is vir ons om kulturele redes nie te verbreek nie. Iemand xan vra: waarom nie ge$x$ ies tussen $v$ en $f$, ei en $y$ nie? soos $s . J$. du Toit indertyd gedoen het, en ons het tog, afgesien van elename, reeds die $z$ laat vaar en slegs die $s$ behou $(\ldots)$ Om praxtiese redes het dit geen sin on op vrae soos hierdie in te gaan nie," 
Hierteenoor huldíg H.J.J.M. van der Merwe (1967:95) 'n ander standpunt:

"Dit (is) duidelik dat die $f / v-k$ wessie nie maklik onder reëls te bring is nie, en selfs die man met taalhistoriese kennis moet meermale twee maal dink of dit $f$ dan wel $v$ moet wees. Vir die Nederlandskundige is dit makliker in dié opsig dat hy $v$ stemhebbend uitspreek en $f$ stemloos maar dis ' $n$ onderskeiding wat in Af $r$ ikaans verlore gegaan het. Juis daarom vra in mens jou af of ons nie maar die knoop moet deurhak en net of $f$ of moet skryf nie."

Dié argument stel Van der Merwe (1967:86) ook ten opsigte ran $\mathbf{e} \mathbf{x} \mathbf{Y}$.

Hoewel daar heelwat probleme is ten opsigte van so 'n onderskeiding van beginselnorme, moet daar gekonkludeer word dat die Afrikaanse spelling oor die jare in groot mate gestandardiseer is, dit wil sê die beginselnorme is redelik konsekwent toegepas, en dit het onder meer gelei tot die uitskakeling van heelwat vreemde (asook Nederlandse) spelvorme. Venter (1964:168169) vat die kwessie goed saam war hy oor die eerste grondbeginsel sê:

"Die Afrikaanse spelling probeer die spreektaal op die voet volg en wil die uitspraak sover moontlik weergee. Maar terselfdertyd wil dit nie alle vitsprake weergee nie mar alleen die algemeen gebruiklike uitspraak. Tog is dit ook nie alle algemene uitsprake wat die grondslag vorm nie, maar dié van beskafde Afrikaans. Dit bring natuurlik onmiddellik' $n$ subjektiewe oordeel in die spel, naamlik om te bepaal wat algemeen is en wat beskaaf is, en ek glo nie dis altyd vir die Taalkommissie moontlik om dit eksperimenteel vas te stel nie."

Dor die spelnorme word daar hier nie lank uitgewei nie, aangesien dit tot ' $n$ aansienlike mate van detailbespreking sal lei. Ter sake is egter dat hierin spesifieke reèls vir elke bepalde spellingverskynsel betrek word. Hierdie reëls dek die volgende verskynsels fdie verwysing is na die Ausuitgawe van 1964 ):

(1) Die gebruik/nie-gebruik van deeltekens (VI).

(2) Die gebruik/nie-gebruik van koppeltekens (VII).

(3) Die gebruik/nie-gebruik van afkappinqstekens (VIII).

(4) Die gebruik/nie-gebruik van kappies (IK).

(5) Die gebruik van aksenttekens ( $x$ ). 
http://spilplus.journals.ac.za/

Eksteen 187

Die enkel resp. dubbel skryt van vokale en die speiwyse van diftonge (XI).

(7) Die skryf van konsonante (XII) en samevattende reëls oor (die spelling yan meervoudsvorme $(X I I I)$. Die spelling van woorde van vreemde herkoms, waarin daar dikwels verbande gelê word met die reeds genoemde reëls (XIV).

(9) Die gebruik van hoofletters (XV).

(10) Die vas of los skryf van woorde (XVI).

Die laaste twee afdelings, naamlik de gebruik van hoofletters en die vas resp. los skryf van woorde, is streng gesproke nie as spelnorme te beskou nie, mar as skryfnorne, aangesien die betrokke reëls slegs slaan op die verskyning van die betrokke vorme op skrif. Daar is dus geen verband te lê met die genoemde spelbeginsels nie. Eerder is daar verder hierby sprake van $t$ radisie of van ' $n$ ontwikkelende tradisie. Utt die aard van die sak word daar hierby dus eerder van ' $n$ ander tipe norm gebruik gemak, naamlik gebruiksnorme.

Daar word ook verder in die Spelreëls van die Aws voorsiening gemak vir die onderskeiding van variasievorme. Hierby kom daar moontlik van die grootste probleme vir die opsteller van Afrikaanse spelnorme na vore, aangesien daar deur die blote erkenning van die voorkoms van variasies implisiet, of soms eksplisiet, afgewyk word van die konsekwentheid wat deur die spelreëls nagestreef word. Boonop raak die kwessie die hele grondslag van die vasstelling van watter taalvorm (byvoorbeeld die standaardvorm) as uitgangspunt moet dien vir die spellingreëling, Die kwessle word in die volgenoe afoleling behandel.

(L.W. Met Aws hierna word verwys na die 1964-uitgawe.)

In die aws word onder par. 7, van die voorwoord onder 'wisselvorme' verstaan: vorme "met verskil van uitspraak en spelling, maar sonder verskil van betekenis". Dit word dan gestel teenoor "dubbelspellinge" ("byvoorbeeld 'n Afrikaanse en ' $n$ vreemde, mar sonder verskil van betekenis") en "doeblette" ("met verskil van uitspraak, spelling en betekenis"). 
http://spilplus.journals.ac.za/

Eksteen $\quad 188$

In dié verband is die Eerste Grondbeginsel ter sake: "die Afrikanse spelling wil die algemeen gebruiklike uitsprak in beskafde Afrikaans as grondslag aanvar" Isien verder die afdeling Afrikanse spelreëls $I$. Grondbeginsels in die AwS). Dit stel dus twee kriteria: (i) die algemeen gebruiklike uitspraak; en (ii) beskafde Afrikaans. In die bespreking van die Eerste Grondbeginsel (t.a.p.) word dar vervolgens eerstens gemotiveer warom sekere vorme nie erken word nie:

\begin{abstract}
"Op grond van hierdie ootweging [ = die algemeen gebruiklike uitspraak in Afrikaans as grondslag - L.C.E. J moes ons spelvorme soos bailing, hiekel, iesel, loep, ens., weer. Hulle verteenwoordig elkeen ' $n$ uitspraak wat wel in beskaafe Afrikans voorkom, maar wat nie algemeen gebruiklik is nie. Andersyds hou ons rekening met 'beskaafde Afrikaans' en moet ons dechalwe spelvorme soos agint, sperskies, tarmtyn, ens.., afkeur."
\end{abstract}

Vervolgens word daar eksplisiet deur die AWS (t,a.p.) 'erken:

"In ' $n$ jong taal soos Afrikaans is dit egter dikwels nie uit te maak watter van twee en soms meer vorme as die gebruiklikste en tegelyk as beskafde vorm erken moet word nie."

Dit vorm dan die grond vir die aanname dat wisselvorme erken moet word:

"In sulke gevalle is die erkenning van wisselvorme soos die volgende onvermydelik: aalvee nas aalwyn, aattappel najs ertappel, ken naas $k i n$, wôre naas more, nôi naas nooi. Daar bestaan in Afrikaans veral ' $n$ groot verskeidenheid werkwoordelike wisselvorme; byvoorbeeld die volgende tipes: begin, beginne, begint: begoël, begogel; bie, bled, bleë; kla, klagg, klae; skryf, skrywe."

Dit is uit hierdie uiteensetting van die beginsel seker duidelik dat die verskynsel van wisselvorme nie probleemloos is nie. Die aard van die probleem kan voorlopig soos volg gestel word: Indien wisselvorme beskou word as vorme wat $n$ ie betekenisverskille vertoon nie, maar slegs fonetiese/ortografiese verskille, is die afleiding dan korrek dat 'n skriftelike taalgebrulker van Afrikaans enigeen van die vorme wat as wisselvorme erken word deur die Taalkommissie, mag gebruik? Op die oog af blyk dit wel die geval te wees.

' $n$ Ondersoek van slegs die wisselvorme wat hierbo genoem word, lei tot die volgende skema: 
http://spilplus.journals.ac.za/

1. WISSELVORME VOLGENS REGIONALE VERSKILLE

aalwee : aalwyn

nôi : nooi

begin : beginne ; begint

I1. WISSELVORME VOLGENS IDIOLEKTIESE VERSKILLE

ken : $k$ in

môre : more

III. WISSELVORME VOLGENS SISTEMATIESE KLANKWISSELINGSPATRONE

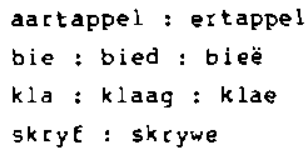

IV. WISSELVORME VOLGENS CHRONOLERTIESE VERSKILLE

ken : $k i n$

begoël : begogel

begin : beginne : begint

Vir die oomblik is dit nie ter sake of ons hierby vorme aantref wat in meer as een afdeling (kan) tuishoort nie. Wat wel van belang is, is dat ons reeds kan vasstel dat nie al die vorme op dieselfde vlak van taalgebruik voorkom nie: daar is onder andere sowel stilistiese as registerverskille aantoonbar, terwyl dar ook taalsistematiese verskynsels voorkom.

5.2 Problematiese aspekte

Dit is teen hierdie agtergrond dat die afdeling oor wisselvorme in die Spelreëls van die aws (pp. 3 e.v.) nader ondersoek moet word. Met die oog op oorsigtelikheid word daar van die bostaande voorlopige indeling gebruik gemaak. 
http://spilplus.journals.ac.za/

Hoewel die aws nie eksplisiet wys op die verskynsel van streeksverskille nie, is dit uit die behandeling van die stof duidelik dat regionaliteit van gebruik implisiet as kriterium aangewend word. So word daar in par. 1. onder III, wisselvorme $(p, 3)$ gesê:

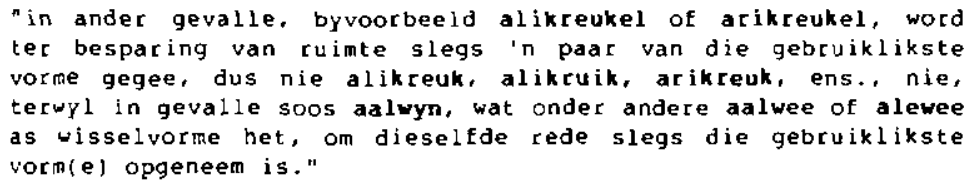

Daar word nie 'n kriterium gegee warvolgens die "gebruiklikste vorme" vasgestel word nie, maar slegs "'n par van die gebruiklikste vorme" word gegee. Indien daar ' $n$ antal vorme voorkom, en die vorme word almal beskou as die gebruiklikste vorme, is dit nie duidelik op water grondslag slegs sekere van die vorme as wisselvorme gekies word nie. Nou word die probleem implisiet ingesien deur die opstellers van die aws, maar dit word op ' $n$ eienaardige manier opgelos, want in die genoemde paragraaf lui dit verder;

"As ' $n$ vorm ontbreek, beteken dit nie sonder meer dat so ' $n$ vorm goedkeuring of afkeuring verdien nie, en word gebruikers van die wordelys aangeraai om in verband daarmee uitvoeriger bronne te raadpleeg."

Daar word nie gesê wat hierdie "uitvoeriger bronne" is nie.

Kyk 'n mens byvoorbeeld in waT I onder alikruik word daarby ook alikruikel, alikreuk(el) as "erkende wisselvorme" gegee, teenoor die Aws se Woordelysopgawe wat slegs alikreukel en arikreukel het. Dus het die wat vyt "erkende wisselvorme" (volgens die Inleiding dié wat soos die lemma ook vet gedruk word), warvan slegs een, alikreukel, een van die twee is wat in die Aws opgeneem is. Die WAT sè verder: "Die vig. vorme kom ook voor: alikruk, alikurk, arikruik(el), arikreukel, arikruk(kel), arrekrekel": in dié geval word die vorme kursief gedruk, met die implikasie dat hulle dan wel wisselvorme is, mar moontlik nie erkende wisselvorme nie. Tog is een hiervan. arikreukel, een van die Woordelys se twee vorme. Hierby gee die Aws in die hierbo aangehaalde paragraaf by implikasie ook alikreuk, alikruik, arikreuk as van die gebruiklikste vorme wat dan wel nie opgeneem word in die woordelys nie, aangesien "slegs " $n$ paar" hiervan gegee word. 
By aalwyn vind ons 'n soortgelyke patroon: die Woordelys gee slegs aalwee en alwy: die hierbo gesiteerde paragraat noem dan ook nog alewee. WAT 1 gee s.v. aalwee ook aalwyn en alewee as "erkende wisselvorme" en noem dan die volgende as "gewestelike vorme": alwee, allewee, alwie en alwy.

Die WAT is moontlik te beskou as een van die "uitvoeriget bronne" wat die AwS in die reeds aangehalde paragraat op die oog het, maar dit gee heeltemal ' $n$ ander leiding aan die gebruiker as die Aws.

Dit sou hier gestel kan word dat die probleem lê by die ineksakte vasstelling van wat as wisselvorme beskou moet word, byvoorbeeld deur gewag te maak van "gebruiklikheid" sonder dat daar aangedui word hóé "gebruiklikheid" as norm aangewend moet word. Boonop is daar ' $n$ belangrike aspek wat ten opsigte van streekswisselvorme buite rekening gelaat word, naamlik dat ' $n$ bepaalde vorm of bepaalde vorme moontlik regionaal sterk kan wissel ten opsigte van "gebruiklikheid". Dit kan byvoorbeeld wees dat sprekers in een gebied die een vorm, sê maar aalwyn, as die algemene of gebruiklike vorm ken, mar dat sprekers in ' $n$ ander gebied ' $n$ ander vorm, sê mar aalwee, algemeen ken en gebruik.

Om ' $n$ warde vic die gebruiker te hê, moet regionale wisselvorme presieser vasgestel (kan) word en die norm van gebruiklikheid, indien vasstelbaar op grond van die ondersoekte data, moet noukeurig geformuleer (kan) word. Alternatiewelik kan die vraag gestel word of regionale wisselvorme hoegenaamd in ' $n$ handleiding oor die spelling var standardafrikaans opgeneem moet word. Hierby kom ' $n$ verdere vraag na vore: indien wisselvorme nie vasstelbaar ' $n$ gelyke verspreiding onder taalgebruikers vertoon nie, behoort sulke vorme wel in ' $n$ spellingreëling betrek te word? Dit laat die vraag na vore kom of die nocm nie veral gerig moet wees op die vasstelling van wat as wisselvorme geld nie, met ander woorde op' 'n definisie.

Dié kwessie word aktueel wanneer daar ook gekyk word na die ander tipes wisselvorme wat onderskei kan word.

Sekere vorme wat in die Aws as wisselvorme angedui word, berus moontlik op die verskynsel dat individuele sprekers uitspraakvorme gebruik wat in die spelling gereflekteer kan word. Behalwe gevalle soos môre : wore en ken : 
kin, wat reeds hierbo genoem is, word daar eksplisiet in par. l by reël III (p. 3) gesê "bepaalde tipes wisselvorme is nie in die woordelys opgeneem nie", mar hulle word wel vermeld. Dit geld gevalle soos dae : dage, hoër : hoger, oë : oge, teoloë : teologe, warby die tweede vorme, dit wil sê die met -g-, wel erken word, mar by implikasie as uitspraakvariante. Idiolekties is daar sekerlik sprake van alternatiewe uitsprakvorme, maar dit is nie ter sprake by die spellingreëling nie, aangesien een vorm vir die spelling erken word. Die ander tipe gaan oor die optrede van ge- voor verlede deelwoorde op -eer, warby slegs die vorme op ge- opgeneem word, hoewel daar ander vorme voorkom warby ge- ook weggelaat kan word (byvoorbeeld loseer, akeer, probeer, regeer, studeer, wardeer). Hierdie gevalle word in ' $n$ reeks opmerkings uitgebrei, mar die opmerkings raak streng gesproke nie die spelling nie, mar die grammatikale (veral sintaktiese) optrede daarvan. Dié aspek, terloops, betrek 'n opvallende eienskap van die spelreëls: dikwels word nie die spellingreëling nie, maar wel grammatiese beskrywing in die uiteensetting betrek. Die aangeleentheid kom weer passim in hierdie artikel ter sprake.

By die beoordeling van hierdie idiolektiese vorme kom ook die chronolektiese wisselvorme te pas, want dit is soms moeilik vas te stel of die betrokke vorme slegs onder bepaalde (ouer) Afrikanse gebruikers voorkow, en of die vorme dalk reeds verouder is.

Dit val op dat die vorme wat as chronolekte beskou kan word, in die Aus in par. 3. van die afdeling oor wisselvorme (vergelyk pp. 4-5) betrek word in 'n algemene saamgroepering van "enkele tipes wisselvorme wat in die besonder die aandag verdien". Opmerklik hier is dat die invloed van Nederlandse vorme op Afrikaans dikwels na vore kom; daar kan ook beweer word dat Afrikaans in sommige gevalle die Nederlandse vorme bestendig het. So byvoorbeeld het die slot -t (op skrif ook - d) in bepaalde woorde van Nederlandse oorsprong in Afrikaans sistematies verval, maar in enkele gevalle is dit behou. Die vorm sonder $-t$ in dié gevalle kan as chronolekties beskou word, aangesien die vorm met $-t$ om bepalde redes (waaronder voorskrif en tradisie kan ressorteer), in Afrikaanse bestendig is. Voorbeelde hiervan is agt, eaagd, sist (med.), takt, borstrok, groots. 
http://spilplus.journals.ac.za/

Aan die ander kant kom daar vorme voor warby die Nederlandse vorm as chronolekties kan geld, omdat die betrokke vorme in die groter en algemene patroon van slot-t-opruiming inpas; voorbeelde is kosthuis en kript.

Derdens is daar ' $n$ aantal gevalle, en hulle sou dan wel as wisselvorme gekenskets kan word, warby die vorme met en sonder t albei gebruiklik in Afrikaans geword het, byvoorbeeld ag : agt, meesal : meestal.

mutat is mutandis geld die bogenoemde opmerkings ook vir die behoud van -nby afleidings; vergelyk geveteloos : gewetenloos, meedoëloos : needoënloos, leweloos : lewensloos, geweteloos : gewetenloos, buite-egtelik : buitenegtelik.

As gevolg van bepaalde fonologiese, morfonologiese en morfologiese, asook dalk sintaktiese, sisteemkenmerke van Afrikaans kan daar ' $n$ wye verskeidenheld wisselvorme onderskei word. oit is onder meer daarin geleë dat sekere klankkombinasies, resp, morfonologiese/morfologiese pacrone, sistematiese variasie vertoon.

Een van die algemene sisteemvariasies wat hom in Afrikaans voordoen, raak die optrede van ' $n$ stemlose frikatief in die auslaut van werkwoorde wat varieer met die voorkoms van die ooreenkomende stemhebbende frikatief gevolg deur die neutrale vokaal in die betrokke posisie: vergelyk gevalle soos beef : bewe, leef : lewe, skaaf : skawe, skryf : skrywe, swert: swerwe. Nog sulke algemene variasies kan onderskei word ten opsigte van die optrede van meervoudsuitgange, onder meer -e : $-\mathbf{s}$; die wisseling van $f$ : in intervokaliese posisie; die optrede van allomorfiese agtervoegsels, byvoorbeeld-loos : -eloos; die wisseling tussen a : e of as- : ee, ensovoorts.

Hierdie wisselinge, wat ook grammatiese wisselvorme genoem kan word, betref Jikwels die optrede van bepalde vorme in 'n sekere fonologiese, morfologiese of sintaktiese omgewing, en die uiteensetting daarvan hoort tot die sisteembeskrywing van die betrokke taal, met ander woorde tot in grammatika, en is nie as sodanig ter sake vir die spellingreëling nie, aangesien die spelvorm self ondervang word deur die reëls wat die optrede van onder meer vokale en konsonante in die betrokke woordvorme uiteensit. 

verskille, as gevolg van 'n sistematiese wisseling -.- na vore tree dat dit as wisselvorme ter sake raak by die spellingreëling.

Die reëluiteensetting in reël III oor "wisselvorme" in die Aws is juis hoofsaaklik gramaties van aard, en die eintlike wisselvorme of heteronieme (= heterograwe) word nie uitgelig nie, maar in die geheel van die bereëling betrek. Dit is duidelik dat dié aspek nog nie rasioneel bereël is nie en as opdrag vir die betrokke taalkommissies voor hande lê.

Trovens, die huidige bereëling van die spelreëls toon dikwels hierdie digotomie tussen grammatikale reëls en spelreëls, ook in ander afdelings van die betrokke reëls as slegs dié in verband met wisselvorme.

Nietemin, al word daar gekom by 'n meer presiese bereëling van die identifikasie van wisselvorme, bly daar nog die probleem oor van die werkike algemene gebruik van sulke alternatiewe vorme. Dit is nie altyd seker dat die aangegewe vorme wel die toets van gelyke gebruiklikheid deurstaan nie. op grond van ' $n$ beperkte en voorlopige ondersoek van Taljard (19B4) blyk onder meer die volgende (slegs in keuse uit die bewerkte materiaal word ter illustrasie gegee); die resultate word in persentasies uitgedruk: 
(1) In keuse van gevalle waar die ondervraagdes slegs een van die betrokke vorme ken/gebruik:

$$
1008
$$

aalwyn

agterlosig

antibiotika

ballonne

beslommernis

beverasie

boerewors

buite-egtelik

chloried

daagliks

disinfekteer

disorganiseer

digby

dioksied

drakrag

gemsbok

kommunikeer

naelskrap
08

asluee

agtelosig

antibiotikums

ballons

bes lomper $r$ ing

bibberasie

boerwor 5

buitenegtelik

chloriede

daeliks

desinfekteer

desorganiseer

digteby

diokside

draagkrag

gensbok

komaniseer

naelskraaps

(2) 'n Keuse van gevalle war die meerderheid van die informante ' $n$ bepaalde vorm ken en gebruik.

(i) 958

dasrenteen

disintegreer

doodsberig

drumpe 1

druipeling

ensovoorts

ewenwel

galop

inkoopprys

aankoopprys

monopol ieë
58

daarenteë

desintegreer

doodberig

drempel

druipling

ensovoort

everel

galoppeer

inkoopsprys

aankoopsprys

monopolies 


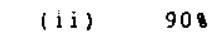

agt, agtste

babatjie

begrawe

disillusioneer

erfenis

gelatien

gliserien

ipekonders

\section{(iii) 858}

allawêreld

bewe

bensien

bokantste

bollemakiegie

bowenal

(iv) 708

dopel ing

kitarar

koöptering/koöptasie

matstawwe

Noorweër

restaurant

a iek tever lof
108

ag, agste

babet jie

begraaf

desillusioneer

exfnis

gelatine

gliserine

hipokonders

$15 \%$

a l lewêreld

beef

bens ine

bokantse

bolmakiesie

boweal

308

doopling

ghitaar

koöpsie

natstawe

Noor

restourant

si ekever lof

Hieronder volg in keuse van gevalle war die keuse min of meer ' $n$ gelyke verdeling vertoon:

$$
\text { (i) } \pm 60 \text { s }
$$

aandelesertifikat (608)

addenduras (638)

benuud (628)

bontebok (658)

gelykgeregtig (608)

kanstig (658)

maksimum prys (608)

marionetspel (638)

minimum prys (658)

Noorweegs (608)

wesenlik (65) $\pm 408$

aandeelsertifikaat (408)

addenda (378)

benieud (388)

bontbok (358)

gelykber egt ig (40)

kantig (358)

maksinumprys (408)

marionet tespel (378)

minimumprys (35)

Noors (408)

wesentlik (358) 
http://spilplus.journals.ac.za/

Die proefgroep het bestaan uit 20 informante (almal moedertaalsprekers van Afrikaans): 10 volwassenes en 10 senior leerlinge; almal behoort tot die bemiddelde klas en is in die pretoria-witwatersrand-Vereeniginggebied woonagtig. Hulle moes op grond van ' $n$ voorgelegde keuselys uit die wisselvorme in die woordelys van die Aws ' $n$ onmiddeilike besluit neem.

Uit die aard van die saak is die ondersoek onvolledig, maar sekere voorlopige konklusies kan wel getrek word:

(1) Die gebruik van wisselvorme in die geskrewe taalgebruik toon ' $n$ wye verskeidenheid: van algemeen gebruiklik oor verkieste vorme heen tot by ' $n$ duidelik merkbare gelyke gebruik.

(2) Die voorkoms van sekere tipes wat min of meer algemeen gebruik word, verdien nadere ondesoek, mar dit is opvallend dat bepaalde vorme min of glad nie gebruik word nie conder meer ten opsigte van die uitgange -ien/-ine: -ied/-ide).

(3) Die feit van gebruiksnorme by wisselvorme word deur die betrokke ondersoek onderstreep.

Die hele aangeleentheid verdien dus 'n noukeurige en diepgaande ondersoek.

\section{$6 \quad$ Afsluiting}

In dié artikel kon daar slegs op ' $n$ aantal felevante sake kortliks die aandag gevestig word, met ' $n$ aanduiding van sekere prosesse, ontwikkelings en problematiese gebiede. Dit is niks meer as ' $n$ voorlopige verkenning van die terrein nie. 
http://spilplus.journals.ac.za/

Die geskiedenis van die Aftikaanse spellingreëling toon egter duidelik aan dat die opeenvolgende normopsteliers steeds beweeg in die $t$ igting van die vasstelling van die presiese norme wat moet geld by die reëling van die Afrikaanse spelling. Intussen is die breëre standaardisasie van die Afrikaanse spelling reeds' ' $n$ voldonge teit, maar tans word die aandag spesifiek gevra vir die presiese identifikasie van probleemgebiede, die duidelike spellinggerigte formulering van die betrokke verskillende tipes norme wat $v i r$ so ' $n$ spellingreëling geld, en die onderskeiding van die verskil tussen 'n spelilingnorm en 'n skryfwysenorm. 


\section{BIBLIOGRAFIE}

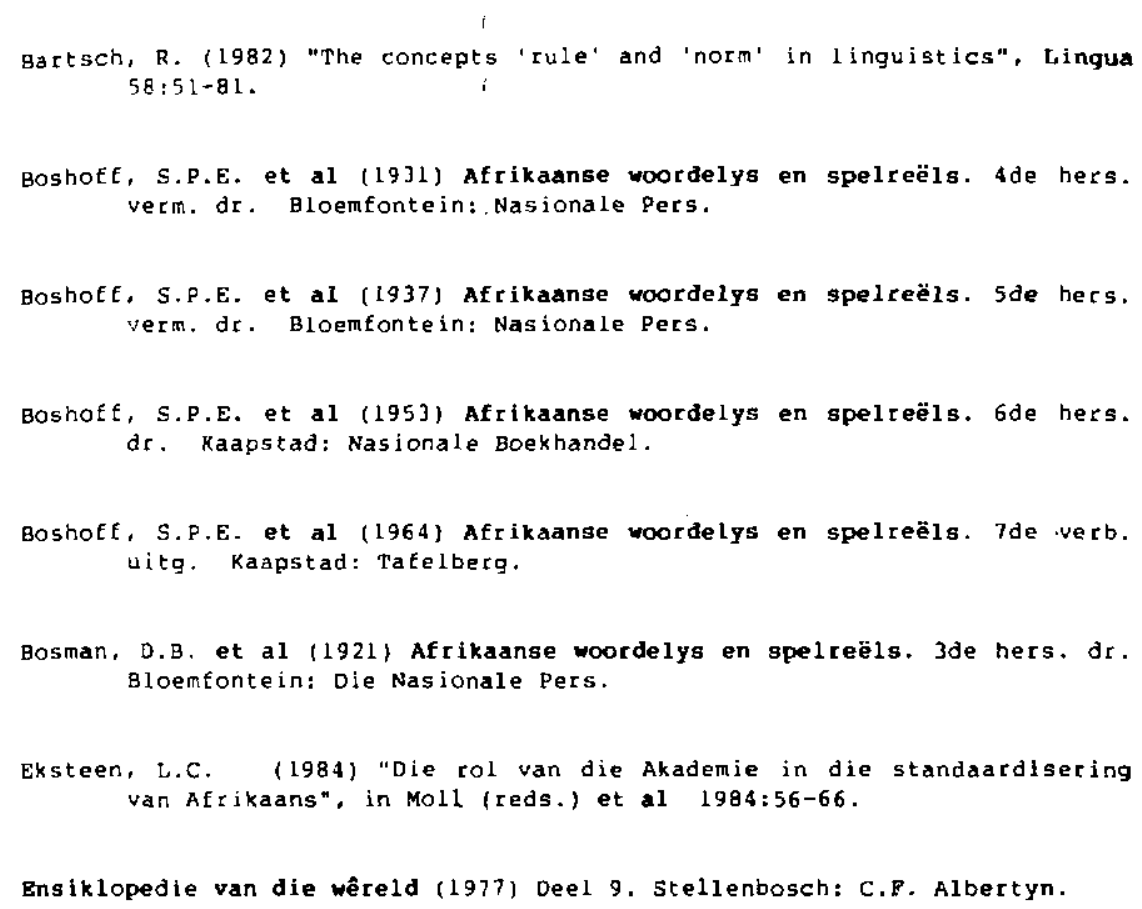

Bosman, D.B. et al (1921) Afrikaanse woordelys en spelreëls. 3de hers, dr. Bloemfontein: Die Nasionale Pers.

Exsteen, L.C. (1984) "Die rol van die Akademie in die standaardisering van Afrikaans", in Moll (reds.) et al 1984:56-66.

Ensiklopedie van die wêreld (1977) Deel 9. Stellenbosch: C.F. Albertyn.

Le Roux, T.H. et al (1917) Afrikaanse roordelijs en spelreëls. lste dr. Bloemfontein: De Nationale Pers.

Le Roux, T.H. et al (191B) Afrikaanse woordelifs en spelreëla. 2de dr. Bloemfontein: De Nationale Pers.

Le Roux, T.H, (1959) "Die Taalkommissie in diens van die AErikaanse volk", in Schumann et al (reds, 1959:44-47.

Malan, S.I. (1963) Die spelling van Afrikaans. D.Litt,-proefskrif, U.O.V.S. Durban: [0ie skrywer].

Moll, J.C. et al (reds.) (1984) Akademie 75. Pretoria: S.A. Akademie vir Wetenskap en kuns.

Schumann, T.E.W. et al (reds.) (1959) Peegalbu 1909-1959. Pretoria: Van Schaik. 
http://spilplus.journals.ac.za/

Eksteen $\quad 200$

SESA ( : Standard encyclopaedia of sowthern Africa) (1970) vol. I. Cape Town: Nasou.

Ta!jard, D.C. (1984) "Wisselvorme". B.A. Hons.-opstel. Departement Afrikaans: U.P. (ongepubliseer).

Van der Merwe, H,J.J.M. (1967) Die korrekte woord. Sde dr. Pretoria: Van Schaik.

Zuid Afrikanse Akademie voor Taal, Letteren en Kunst, De, (1915) Jaarboek VI. Bloemtontein, Potchetstroom: "Het Volksblad"-drikkerij. 